\title{
A Study of Process Skills in Mathematics: Elementary School and Madrasah Ibtidaiyah
}

\section{Husni Sabil1, Asrial2 ${ }^{*}$, Syahrial ${ }^{3}$, Rahmi ${ }^{4}$, Adriyan Ardi Rahman ${ }^{5}$}

1,2,3,5 Faculty of Teaching and Education, Universitas Jambi, Jambi, Indonesia

${ }^{4}$ Faculty of Teaching and Education, Universitas Muhammadiyah Sumatera Barat, Sumatera Barat, Indonesia

\section{ART I C L E I N F O}

\section{Article history:}

Received July 13, 2021

Revised July 14, 2021

Accepted September 30, 2021

Available online November 25, 2021

\section{Kata Kunci}

Pembelajaran, Matematika

Keterampilan Siswa

Keywords:

Learning, Mathematics, Student Skills

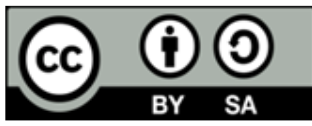

This is an open access article under the CC BY-SA license.

Copyright (@) 2021 by Author. Published by Universitas Pendidikan Ganesha.

\section{A B S T R A C T}

\begin{abstract}
A B S T R A K
Matematika merupakan pembelajaran yang banyak menggunakan bilangan sehingga banyak siswa yang tidak menyukai matematika. Penelitian lain juga menyatakan bahwa siswa merasa kesulitan dalam belajar matematika. Tujuan penelitian ini yaitu untuk membandingkan dan menghubungkan keterampilan siswa sekolah dasar dan siswa sekolah islam pada materi perkalian pecahan. Penelitian ini menggunakan metode kuantitatif dengan jenis assosiatif dan komperatif. Populasi pada penelitian ini sebanyak 36 siswa dimasing masing sekolah. Instrumen penelitian ini keterampilan proses siswa antara SD (Sekolah Dasar) dan MI (Madrasah Ibtidaiyah) terhadap pelajaran matematika materi perkalian pecahan. Penelitian ini menguji statistik deskriptif setelah melakukan uji statistik deskriptif dan uji asumsi berupa uji normalitas dan uji homogenitas dan uji linieritas. Hasil penelitian yaitu siswa $S D$ dan siswa MI data dikatakan normal serta data bersifat homogen dan terdapat hubungan yang linier antara siswa $S D$ dan siswa MI. Terdapat keterampilan proses siswa antara siswa di SD (Sekolah Dasar) dan MI (Masrasah Ibtidaiyah) dalam pembelajaran matematika materi perkalian pecahan. Dari hasil uji korelasi masing masing sekolah menunjukkan bahwa respon siswa berpengaruh terhadap keterampilan proses belajar siswa.
\end{abstract}

Mathematics is learning that uses many numbers, so that many students do not like mathematics. Other research also states that students find it difficult to learn mathematics. The purpose of this is to compare and relate the skills of elementary school students and Islamic school students to the material. This study uses quantitative methods with associative and comparative types. The population in this study were 36 students in each school. The research instrument for students' process skills between SD (Elementary School) and MI (Madrasah Ibtidaiyah) on mathematics lessons. This study tested the statistics after performing statistical tests and assumption tests in normality tests, homogeneity tests, and linearity tests. The study results are that the data of SD and MI students are said to be expected, and the data are homogeneous, and there is a linear relationship between SD and MI students. There is a process of student skills between students in SD (Elementary School) and MI (Masrasah Ibtidaiyah) in learning mathematics. The correlation test results for each school shows that student responses affect students' learning process skills.

\section{INTRODUCTION}

Education is a very important thing in today's modern era. Humans need education to be useful for society and the nation, thereby producing intellectual generations to increase knowledge (Dang, 2021; Faisal \& Martin, 2019; Kebritchi et al., 2017). Education is a learning process for students so that they can know, evaluate and apply any knowledge gained. Education is an activity to optimize the development of potential, skills, and personal characteristics of students (Bui \& Do Van Dung, 2019; Dhanalakshmi et al., 2021; Hendawi \& Nosair, 2020). Education is directed at developing students' potential and skills so that they can be used in living life in society, nation and state (Jayadiputra \& Karim, 2020; Kidd et al., 2020; Komalasari \& Rahmat, 2019). In educators there are learners who help students to progress. 21st century learning does not only focus on memorizing material but also emphasizes learning and thinking skills, and social life skills (Kivunja, 2015; Luciana, 2020; Rusydiyah et al., 2021). Learning is not only studying theory 
and facts but also studying applications in society (Churchill et al., 2013; Haviz et al., 2020; Hirschman \& Wood, 2018). While studying, students have a type of learning to increase learning motivation and increase creativity (Lavi et al., 2021; Rizaldi et al., 2020; Stover et al., 2016). Learning is made based on the competence of students' needs. Students are an educational component that cannot be abandoned, because without students, the learning process cannot be carried out. Students have the ability and speed in absorbing learning materials so that more than books are needed to be able to guide students to become active in learning independently (Horasan-Doğan \& Cephe, 2020; Nurtanto et al., 2019; Puspita, 2019). Learning is useful for making students gain insight and learning can be done effectively if teaching materials support learning activities (Handayani et al., 2021; Matsun et al., 2019; Sorensen, 2013). One of the learning materials is mathematics, mathematics learning is related to numbers (Hasiana \& Wirastania, 2018; Rekysika \& Haryanto, 2019; Suarsana, 2021).

Mathematics learning is learning that makes students think logically, can analyze data, systematically and others (Banks et al., 2018; Kowiyah \& Mulyawati, 2018). In Indonesia, students have received mathematics material since elementary school (Choridah, 2013; Ngilamele et al., 2019; Widodo, 2006). Learning mathematics in the form of numbers, counting, using an abstract model (Istuningsih et al., 2018; Kartika et al., 2019; Kubilinskiene \& Dagiene, 2010). Because mathematics is a learning that uses a lot of numbers so that many students do not like mathematics. Other research also states that students find it difficult to learn mathematics (Netriwati, 2018; Shofiah et al., 2018; Wahyuniar \& Widyawati, 2017). Mathematics is one of the learning materials related to numbers. The ultimate goal of learning mathematics is that students can apply some mathematical material into everyday life (Darmani \& Renaldi, 2018; Ratnawati et al., 2020; Setianingrum et al., 2020). In addition to studying numbers, mathematics is also a scholar who studies all of nature (Aziz et al., 2020; Kowiyah \& Mulyawati, 2018; Suarsana, 2021). Mathematics lessons have been taught since elementary school, one of the first materials taught is fractions (Diantari, 2019; Moh'd et al., 2021; Rahmiati \& Fahrurrozi, 2016). So that students can understand mathematics learning process skills can affect student learning outcomes.

Process skills are one way for students to understand learning. Skills are very important for students to increase creativity and knowledge through learning activities (Aziz et al., 2020; Stender et al., 2018; Vartiainen \& Kumpulainen, 2020). One of the student skills is being able to acquire analytical concepts and observations (Bortnik et al., 2017; Harta et al., 2020; Mullis et al., 2012). Student skills can be obtained from learners who require students to experience for themselves, seek, try, and draw conclusions (Kruit et al., 2018; Mutlu, 2020; Solé-Llussà et al., 2019). This research is in line with previous research on student skills. However, previous studies only used variables regarding student process skills at the general school level. So that in previous research it was not known the difference in student process skills between public schools and Madrasah Ibtidaiyah (Ihsan, I. A. \& Saputra, 2019; Pamungkas et al., 2019). Therefore, the purpose of this study was to compare and relate the skills of elementary school students and Islamic school students in the multiplication of fractions material. So the urgency of this study is to find out the results of students' process skills indicators regarding: observation, classification, compiling tables, and measuring. And looking for differences and relationships between elementary and MI students' process skills with fractional multiplication.

\section{METHOD}

This study uses quantitative associative and comparative research using a survey procedure by comparing the process skills of students from 4 classes to the material. Creswell (2002) survey research design is a procedure in quantitative research in which the research administers a survey of a sample or population for the purpose of describing the attitudes, opinions, behaviors, or characteristics of the respondents. The samples in this study were 36 students from SDN 63/I Simpang Karmio, 36 students from SDN 04/I Sungai Ruang Ilir, 36 students at MIN 3 Batang Hari and 36 students from MIS Nuru Jidad. The sampling technique used in this study used simple random sampling. Using random sampling can reduce the potential for bias in the selection of cases to be included in the sample. With the condition that random sampling is done because of the homogeneous population, the sampling frame is clear and general in nature. The reason for taking this technique is because not all samples have criteria that match the phenomenon being studied. The samples taken were students from class 5A in each school, namely SDN 63/I Simpang Karmio, SDN 04/I Sungai Ruang Ilir, MIN 3 Batang Hari, and MIS Nurul Jidad. The instrument in this research is process skills. The assessment instrument is one of the most important assessment instruments for attitudes (Suratmi et al., 2020). The collection of research data comes from research instruments that come from questionnaires. Processing skills instrument in the form of a questionnaire with 47 valid question items and this instrument uses a Likert scale. The scale consists of 4 points with a score of strongly agree is 4 , agree is 3 , disagree is 2 , and strongly disagree is 1 . Each statement is representative of each attitude 
indicator. The focus of this research is on 17 dimensions of processing skills, namely observation, communication, classification, measuring, inferring, predicting, compiling tables, obtaining and processing data, analyzing experiments, making hypotheses, designing experiments, and conducting experiments. For the questionnaire grid for this research, it can be seen in table 1 .

Table 1. Grid of Student Process Skills Questionnaire Instruments on Fraction Multiplication Material Materi

\begin{tabular}{ccc}
\hline Variable & Indicator & $\begin{array}{c}\text { No. Statement } \\
\text { Items }\end{array}$ \\
\hline & Observation & $1,2,3$ \\
& Communication & $4,5,6,7$ \\
$8,9,10,11,12$ \\
Classification & $13,14,15$ \\
Process Skills of students on & Measure & $16,17,18,19$ \\
the material multiplication of & Conclusion & $20,21,22,23,24$ \\
fractions & Prediction & $25,26,27$ \\
& Arrange Table & $28,29,30,31$ \\
& Obtaining and Processing Data & $32,33,34,35$ \\
& Experimental Analysis & $36,37,38$ \\
& Creating a Hypothesis & $39,40,41,42,43$ \\
& Designing Experiments & $44,45,46,47$ \\
\hline
\end{tabular}

Because the student's process skills questionnaire on the material of multiplication of fractions uses a Likert scale, there is an interval for each indicator that is tested. The intervals for the indicators tested can be seen in table 2 .

Table 2. Category of Student Process Skills Against Fraction Multiplication Material

\begin{tabular}{lcccc}
\hline \multirow{2}{*}{ Category } & \multicolumn{3}{c}{ Indicator Interval } \\
\cline { 2 - 5 } & Observation & Classification & Arrange Table & Measure \\
\hline Very Not Good & $3.0-5.25$ & $5.0 .-8.75$ & $3.0-5.25$ & $3.0-5.25$ \\
Not good & $5.26-7.50$ & $8.76-12.5$ & $5.26-7.50$ & $5.26-7.50$ \\
Good & $7.51-9.75$ & $12.6-16.25$ & $7.51-9.75$ & $7.51-9.75$ \\
Very good & $9.76-12.00$ & $16.26-20,0$ & $9.76-12.00$ & $9.76-12.00$ \\
\hline
\end{tabular}

The Likert scale used in this study were: 1 (very not good), 2 (not good), 3 (good), 4 (very good) with 48 questions about students' processing skills on multiplication of fractions material. The results of students' questionnaire answers regarding processing skills were analyzed using descriptive statistics. By using this type of associative research to determine the relationship or type of the variables used. Therefore, differential statistics are used with assumption tests consisting of normality, linearity and homogeneity tests as well as hypothesis testing, namely $\mathrm{T}$ test and correlation test. The nomarality test aims to determine whether a data can be said to be normal or not, while the homogeneous test aims to determine whether the data of the two samples is homogeneous or not. The normality test was obtained from the result data in a normally distributed population with the condition that the sig value was greater than 0.05 . The first step in this research is to determine the normality and homogeneity of a data using normality test and homogeneity test. Normality test and homogeny test if the result data in the population is normally distributed and homogeneous, then the condition is that the sig value is greater than 0.05 .

\section{RESULT AND DISCUSSION}

\section{Result}

The results obtained from the school data of SDN 63/I Simpang Karmio, SDN 04/I Sungai Ruang Ilir, MIN 3 Batang Hari, and MIS Nurul Jidad for grade 5A are as follows. The description of the process skills of SD/MI students on the multiplication of fractions material on the Observation indicator. Based on the results of data analysis, the process skills of SD/MI students with observation indicators found that on average many students chose the good and very good categories with the percentage for SD N 63 38.9\% good and 30.6\% very good, SD N 04 38.9\% good and 33.4\% very good, MIN 3 41.7\% good and 27.8\% very good, MIS Nurul Jadid $36.1 \%$ good and $33.4 \%$ very good. Furthermore, the process skills of SD/MI students 
with measuring indicators. Based on the results of data analysis, the process skills of SD/MI students with measuring indicators found that the average number of students chose the good category with the percentage for SD N 63 47.2\% good, SD N 04 36.1\% good, MIN 3 30.5\% good, MIS Nurul Jadid 36.1\% good.

Furthermore, the process skills of SD/MI students with indicators compose a table Based on the results of data analysis, the process skills of SD/MI students with indicators in compiling the table, it was found that on average many students chose the bad and good categories with the percentage for SD N 63 $30.6 \%$ not good and 33.3\% good, SD N $0433.3 \%$ not good and 33.3\% good, MIN 3 33.3\% is not good and $41.7 \%$ is good, MIS Nurul Jadid 33.3\% is not good and 33.3\% is good. Furthermore, the process skills of $\mathrm{SD} / \mathrm{MI}$ students with classification indicators. Based on the results of data analysis, the process skills of $\mathrm{SD} / \mathrm{MI}$ students with indicators in compiling the table showed that the average number of students chose good with the percentage for SD N 63 25.8\% not good, SD N 04 27.2\% good, MIN 3 30\% good, MIS Nurul Jadid $28.6 \%$ good. The data is normally distributed as seen from the significance value, if the significance value is $>0.05$. The results of the normality test are shown in the following table 3 . The normality test for elementary/MI students' process skills on the multiplication of fractions is described in the following table 3.

Table 3. Normality Test of SD/MI students' process skills on multiplication of fractions.

\begin{tabular}{llll}
\hline School name & N & Statistik & Sig. \\
\hline SDN 63/I Simpang Karmio & 36 & 0,978 & 0,675 \\
SDN 04/I Sungai Ruang Ilir & 36 & 0,942 & 0,753 \\
MIN 3 Batang Hari & 36 & 0,940 & 0,668 \\
MIS Nurul Jidad & 36 & 0,983 & 0,724 \\
\hline
\end{tabular}

Based on the results of table 8, it was obtained that the normality test with the KolmogorovSmirnov test had a significance value of $>0.05$, so it can be concluded that the data is normally distributed. This test is carried out in order to find out whether the $\mathrm{x}$ and $\mathrm{y}$ data are homohen or not. The requirement in this test is that if the significance value is $>0.05$, it can be said that the $\mathrm{x}$ and $\mathrm{y}$ data are homogeneous (same). If the significance value is $<0.05$ then the data is not homogeneous (not the same). The results obtained are shown in the table. The homogeneity test of elementary/MI students' process skills on the multiplication of fractions is described in the following table.

Table 4. Test of homogeneity of Elementary/MI Students' Process Skills on The Multiplication Of Fractions Material

\begin{tabular}{llll}
\hline School name & N & F & Sig. \\
\hline SDN 63/I Simpang Karmio & 36 & 0,128 & 0,751 \\
SDN 04/I Sungai Ruang Ilir & 36 & & \\
MIN 3 Batang Hari & 36 & 0,098 & 0,453 \\
MIS Nurul Jidad & 36 & \\
\hline
\end{tabular}

Based on table 9 obtained, the results of the homogeneity test obtained are a significance value of 0.751 for SD and 0.453 for MI that has met the requirements $>0.05$, it can be concluded that the two variables are homogeneous. This test is carried out in order to see a linear relationship between two or more variables. The requirements for this test, if the significance value is $>0.05$. The results obtained are shown in the table. The linearity test of elementary/MI students' process skills on the multiplication of fractions is described in the following table.

Table 5. Linearity test of elementary/MI students' process skills on multiplication of fractions.

\begin{tabular}{lllll}
\hline School Level & School & N & F & Sig. \\
\hline \multirow{2}{*}{ SD } & SDN 63/I Simpang Karmio & 36 & \multirow{2}{*}{1,578} & \multirow{2}{*}{0,241} \\
\multirow{2}{*}{ MI } & SDN 04/I Sungai Ruang Ilir & 36 & & \\
& MIN 3 Batang Hari & 36 & \multirow{2}{*}{1,051} & 0,379 \\
\hline
\end{tabular}

Based on table 10 obtained, the results of the linearity test obtained are a significance value of 0.241 for SD and 0.379 for MI that has met the requirements $>0.05$, so it can be concluded that there is a linear relationship between the process skills of elementary school students and MI students on the material multiplication of fractions. In this test, it is carried out in order to know the difference between the variables 
on the multiplication of fractions material. The conditions in this test are if the significance value is $>0.05$, it can be said that these variables have differences. If the significance value is $<0.05$, then the variable does not have a significant difference. From the data, it can be seen that there are differences in student process skills in each school. This is evidenced by the value of sig (2-tailed) $>0.05$. In this test, it is carried out in order to determine the relationship of variables to the material of multiplication of fractions. Conditions in this test if the significance value $>0.05$ then it can be said that the variable has no relationship. If the significance value is $<0.05$, then the variable has a significant relationship. The results obtained are shown in the table. The correlation test for Elementary and MI Student Process Skills. From the data, it can be seen that there is a relationship between the process skills of Elementary School and Madrasah Ibtidaiyah. This is evidenced by the value of sig (2-tailed) $>0.05$

\section{Discussion}

This research is in line with previous research on students' process skills. However, previous studies only used variables regarding student process skills at the public school level. So that in previous studies it was not known the difference in student process skills between public schools and Madrasah Ibtidaiyah (Ihsan, I. A. \& Saputra, 2019; Pamungkas et al., 2019; Wulandari et al., 2019). To find out the extent to which Madrasah Ibtidaiyah students have a good skill level among other school levels. It is known that Madrasah Ibtidaiyah is a religious school that prioritizes religious lessons so that the process skills of students at Madrasah Ibtidaiyah are not yet known. Many of the skills carried out by other studies have not yet entered the stage of multiplication of fractions learned by Madrasah Ibtidaiyah students. In this study, the researcher chose the student's process skills which aimed to understand the control, thought process, motivational attitude, and psychology faced by elementary school and Islamic elementary school students in learning fraction multiplication material. By testing this, it can be seen that students' process skills have an influence on the development of student learning in mathematics (Kowiyah \& Mulyawati, 2018; Macnab \& Payne, 2003; Suarsana, 2021). With good process skills students can develop knowledge, skills regarding the material of multiplication of fractions (Diantari, 2019; Moh'd et al., 2021; Rahmiati \& Fahrurrozi, 2016). Process skills can evaluate problems related to mathematics subjects. In this way, the good skills of each student are formed (Bosica et al., 2021; Helsa et al., 2021). The essence of this study discusses the differences and relationships in the process skills of elementary school students and madrasah ibtidaiyah students. In other words, these differences and relationships describe students' skills in mathematics. It is known that there are differences and relationships between elementary schools and Madrasah Ibtidaiyah. The disadvantage of this research is that it only measures student skill variables and has not carried out testing with other variables such as attitudes, interests, motivation, learning models and others. So it is advisable to read other articles that contain other variables.

\section{CONCLUSION}

There is a comparison of the process skills of elementary school students and MI students obtained from descriptive statistics that SD N 04/I Ruang Sungai Ilir is superior to other schools tested with indicators of observation, measuring, compiling tables, and classification. As for the comparison of the process skills of elementary school students and MI students to mathematics lessons on multiplication of fractions, it was found that there were differences between schools. Then there is a relationship between the process skills of elementary school students and MI students as evidenced by the correlation test above.

\section{REFERENCES}

Aziz, A. F., Kusumaningsih, W., \& Rahmawati, N. D. (2020). Pengaruh Model Pembelajaran Missouri Mathematics Project (MMP) dengan Strategi Think Talk Write (TTW) Terhadap Kemampuan Pemecahan Masalah Matematika Siswa SMP. Imajiner: Jurnal Matematika Dan Pendidikan Matematika. https://doi.org/10.26877/imajiner.v2i2.5774.

Banks, H. T., Flores, K. B., Langlois, C. R., Serio, T. R., \& Sindi, S. S. (2018). Estimating the rate of prion aggregate amplification in yeast with a generation and structured population model. Inverse

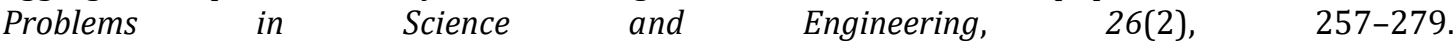
https: //doi.org/10.1080/17415977.2017.1316498.

Bortnik, B., Stozhko, N., Pervukhina, I., Tchernysheva, A., \& Belysheva, G. (2017). Effect of Virtual Analytical Chemistry Laboratory on Enhancing Student Research Skills and Practices. Research in Learning Technology, 25, 1-20. https://doi.org/10.25304/rlt.v25.1968.

Bosica, J., S.Pyper, J., \& MacGregor, S. (2021). Incorporating problem-based learning in a secondary school mathematics preservice teacher education course. Teaching and Teacher Education, 102, 103335. 
https://doi.org/10.1016/j.tate.2021.103335

Bui, V. H., \& Do Van Dung. (2019). Development of Vietnamese Vocational Education Teachers to adapt the Industrial Revolution 4.0. Asian Journal of Interdisciplinary Research, 2(4), 1-7. https://doi.org/10.34256/ajir1941.

Choridah, D. T. (2013). Peran Pembelajaran Berbasis Masalah Untuk Meningkatkan Kemampuan Komunikasi Dan Berpikir Kreatif Serta Disposisi Matematis Siswa Sma. Infinity Journal, 2(2), 194. https://doi.org/10.22460/infinity.v2i2.35.

Churchill, D., King, M., \& Fox, B. (2013). Learning design for science education in the 21st century. Zbornik Instituta Za Pedagoska Istrazivanja, 45(2), 404-421. https://doi.org/10.2298/ZIPI1302404C.

Dang, T. N. Y. (2021). English for Vocational Purposes: Language uses in trades education, Averil Coxhead, Jean Parkinson, James Mackay, Emma McLaughlin, 1st Edition, Routledge, Taylor \& Francis Group, London (2019). English for Specific Purposes, 63. https://doi.org/10.1016/j.esp.2021.04.002.

Darmani, J. W., \& Renaldi, A. (2018). Analisis Kemampuan Pemecahan Masalah Matematis : Dampak Model Pembelajaran Reciprocal Teaching Dengan Fieldtrip. Desimal: Jurnal Matematika, 1(3). https://doi.org/10.24042/djm.v1i3.3108.

Dhanalakshmi, R., Anuja Mary, A., Shrijith, D., \& Vijayaraghavan, N. (2021). A study on Covid-19 - Impacting Indian $\quad$ Materials Todation. Proceedings, https://doi.org/10.1016/j.matpr.2021.02.786.

Diantari. (2019). Pengaruh Model Pembelajaran Missouri Mathematics Project Realistik Berbantuan LKS Terhadap Hasil Belajar Matematika. Jurnal Imiah Pendidikan Dan Pembelajaran, 3(2), 127-136. https://doi.org/10.23887/jipp.v3i2.18069.

Faisal, \& Martin, S. N. (2019). Science education in Indonesia: past, present, and future. Asia-Pacific Science Education, 5(1). https://doi.org/10.1186/s41029-019-0032-0.

Handayani, D., Elvinawati, E., Isnaeni, I., \& Alperi, M. (2021). Development Of Guided Discovery Based Electronic Module For Chemical Lessons In Redox Reaction Materials. International Journal of Interactive Mobile Technologies (IJIM), 15(07), 94. https://doi.org/10.3991/ijim.v15i07.21559.

Harta, J., Rasuh, N. T., \& Seriang, A. (2020). Using HOTS-Based Chemistry National Exam Questions to Map the Analytical Abilities of Senior High School Students. Journal of Science Learning, 3(3), 143-148. https://doi.org/10.17509/jsl.v3i3.22387.

Hasiana, \& Wirastania. (2018). Pengaruh Musik dalam Mengembangkan Kemampuan Mengenal Bilangan Siswa Kelompok A di TK Lintang Surabaya. Jurnal Obsesi, 1(2), 131-138. https://doi.org/10.31004/obsesi.v1i2.25.

Haviz, M., Lufri, L., \& Maris, I. M. (2020). Assessing prospective biology teachers (PBTs) perceptions on thinking as a 21st century skill: A case study at Islamic University. Jurnal Pendidikan IPA Indonesia, 9(3), 319-329. https://doi.org/10.15294/jpii.v9i3.24077.

Helsa, Y., Ariani, Y., \& Kenedi, A. (2021). Digital Class Model in Mathematics Learning in Elementary School Using Social Learning Network Schoology. 382(Icet 2019), 2016-2019. https://doi.org/10.4108/eai.4-11-2020.2304599.

Hendawi, M., \& Nosair, M. R. (2020). Students' technological awareness at the College of Education, Qatar University. Cypriot Journal of Educational Sciences, 15(4), 749-765. https://doi.org/10.18844/cjes.v15i4.5057.

Hirschman, K., \& Wood, B. (2018). 21st century learners: Changing conceptions of knowledge, learning and the child. The New Zealand Annual Review of Education, 23(June), 20. https://doi.org/10.26686/nzaroe.v23i0.5280.

Horasan-Doğan, S., \& Cephe, P. T. (2020). The effects of creative drama on student teachers' creative pedagogy and identity. Thinking Skills and Creativity, 38. https://doi.org/10.1016/j.tsc.2020.100736.

Ihsan, I. A., . M., \& Saputra, H. J. (2019). Keefektifan Model Pembelajaran Student Teams Achievement Division Berbantu Media Puzzle terhadap Keterampilan Berbicara Siswa. Jurnal Ilmiah Sekolah Dasar, 3(4). https: //doi.org/10.23887/jisd.v3i4.21799.

Istuningsih, W., Baedhowi, \& Bayu Sangka, K. (2018). The Effectiveness of Scientific Approach Using EModule Based on Learning Cycle 7E to Improve Students' Learning Outcome. International Journal of Educational Research Review, 3(3), 75-85. https://doi.org/10.24331/ijere.449313.

Jayadiputra, E., \& Karim, A. A. (2020). 21st Century Competences in Civic Education Curriculum of Indonesia. 2nd Annual Civic Education Conference (ACEC 2019), 99-102. https://doi.org/10.2991/assehr.k.200320.019.

Kartika, Y., Wahyuni, R., Sinaga, B., \& Rajagukguk, J. (2019). Improving Math Creative Thinking Ability by using Math Adventure Educational Game as an Interactive Media. Journal of Physics: Conference Series, 1179(1), 1-6. https://doi.org/10.1088/1742-6596/1179/1/012078. 
Kebritchi, M., Lipschuetz, A., \& Santiague, L. (2017). Issues and Challenges for Teaching Successful Online Courses in Higher Education. Journal of Educational Technology Systems, 46(1). https://doi.org/10.1177/0047239516661713.

Kidd, D., Miner, J., Schein, M., Blauw, M., \& Allen, D. (2020). Ethics across the curriculum: Detecting and describing emergent trends in ethics education. Studies in Educational Evaluation, 67. https://doi.org/10.1016/j.stueduc.2020.100914.

Kivunja, C. (2015). Unpacking the Information, Media, and Technology Skills Domain of the New Learning Paradigm. International Journal of Higher Education, 4(1). https://doi.org/10.5430/ijhe.v4n1p166.

Komalasari, K., \& Rahmat, R. (2019). Living Values Based Interactive Multimedia in Civic Education Learning. International Journal of Instruction, 12(1), 113-126. https: //doi.org/10.29333/iji.2019.1218a.

Kowiyah, \& Mulyawati, I. (2018). An analysis of primary school students' representational ability in mathematics based on gender perspective. Journal of Physics: Conference Series, 948(1). https://doi.org/10.1088/1742-6596/948/1/012016.

Kruit, P. M., Oostdam, R. J., van den Berg, E., \& Schuitema, J. A. (2018). Assessing students' ability in performing scientific inquiry: instruments for measuring science skills in primary education. Research in Science and Technological Education, 36(4). https: //doi.org/10.1080/02635143.2017.1421530.

Kubilinskiene, S., \& Dagiene, V. (2010). Technology-Based Lesson Plans: Preparation and Description. Informatics in Education, 9(2), 217-228. https://doi.org/10.15388/infedu.2010.15.

Lavi, R., Tal, M., \& Dori, Y. J. (2021). Perceptions of STEM alumni and students on developing 21st century skills through methods of teaching and learning. Studies in Educational Evaluation, 70, 1-11. https://doi.org/10.1016/j.stueduc.2021.101002.

Luciana, N. L. R. (2020). Teachers' Readiness in Inserting the 21st Century Skills in the Lesson Plan in Teaching English. Jurnal Pendidikan Dan Pengajaran, 53(2), 168. https://doi.org/10.23887/jpp.v53i2.26406.

Macnab, D. S., \& Payne, F. (2003). Beliefs, attitudes and practices in mathematics teaching: Perceptions of Scottish primary school student teachers. Journal of Education for Teaching, 29(1), 55-68. https://doi.org/10.1080/0260747022000057927.

Matsun, Andrini, V. S., Maduretno, T. W., \& Yusro, A. C. (2019). Development of physics learning e-module based on local culture wisdom in Pontianak,West Kalimantan. Journal of Physics: Conference Series, 1381(1). https://doi.org/10.1088/1742-6596/1381/1/012045.

Moh'd, S. S., Uwamahoro, J., Joachim, N., \& Orodho, J. A. (2021). Assessing the Level of Secondary Mathematics Teachers' Pedagogical Content Knowledge. Eurasia Journal of Mathematics, Science and Technology Education, 17(6), em1970. https://doi.org/10.29333/ejmste/10883.

Mullis, I. V., Martin, M. O., Minnich, C. A., Stanco, G. M., Arora, A., Centurino, V. A., \& Castle, C. E. (2012). Encyclopedia: Education Policy and Curriculum in Mathematics and Science. In Pirls (Vol. 1). https://doi.org/10.6209/JORIES.2017.62(1).03.

Mutlu, A. (2020). Evaluation of students' scientific process skills through reflective worksheets in the inquiry-based learning environments. Reflective Practice, 21(2). https://doi.org/10.1080/14623943.2020.1736999.

Netriwati. (2018). Penerapan Taksonomi Bloom Revisi untuk Meningkatkan Kemampuan Pemahaman Konsep Matematis. Desimal: Jurnal Matematika, 1(2). https://doi.org/10.24042/djm.v1i3.3238.

Ngilamele, M., Laamena, C. M., \& Palinussa, A. (2019). Efektifitas Model Pembelajaran Kooperatif Tipe Tai (Teams Assited Individualization) Terhadap Hasil Belajar Materi Himpunan Pada Siswa Smp Maria Mediatrix Ambon. Journal of Honai Math, 2(1), 13-24. https://doi.org/10.30862/jhm.v2i1.51.

Nurtanto, M., Sofyan, H., Fawaid, M., \& Rabiman, R. (2019). Problem-based learning (PBL) in industry 4.0: Improving learning quality through character-based literacy learning and life career skill (LL-LCS). Universal Journal of Educational Research, 7(11), 2487-2494. https://doi.org/10.13189/ujer.2019.071128.

Pamungkas, D., Mawardi, \& Astuti, S. (2019). Peningkatan Keterampilan Berpikir Kritis Dan Hasil Belajar Matematika Melalui Model Discovery Learning Di Kelas IV SD. Jurnal Ilmiah Sekolah Dasar, 3(1). https://doi.org/10.31004/basicedu.v3i1.98.

Puspita, L. (2019). Pengembangan Modul Berbasis Keterampilan Proses Sains Sebagai Bahan Ajar Dalam Pembelajaran Biologi. Jurnal Inovasi Pendidikan IPA, 5(1), 79-87. https://doi.org/https://doi.org/10.21831/jipi.v5i1.22530.

Rahmiati, R., \& Fahrurrozi, F. (2016). Pengaruh Pembelajaran Missouri Mathematics Project (Mmp) Terhadap Kemampuan Pemecahan Masalah Matematika. Jurnal Pendidikan Matematika, 10(2), 112. https://doi.org/10.22342/jpm.10.2.3634.75-86. 
Ratnawati, Handayani, \& Hadi. (2020). Pengaruh Model Pembelajaran PBL Berbantu Question Card terhadap Kemampuan Berpikir Kritis Matematis Siswa SMP. Edumatica: Jurnal Pendidikan Matematika, 10(1). https://doi.org/10.22437/edumatica.v10i01.7683.

Rekysika, N. S., \& Haryanto, H. (2019). Media Pembelajaran Ular Tangga Bilangan Untuk Meningkatkan Kemampuan Kognitif Anak Usia 5-6 Tahun. Cakrawala Dini: Jurnal Pendidikan Anak Usia Dini, 10(1), 56-61. https://doi.org/10.17509/cd.v10i1.16000.

Rizaldi, D. R., Nurhayati, E., \& Fatimah, Z. (2020). The Correlation of Digital Literation and STEM Integration to Improve Indonesian Students' Skills in 21st Century. International Journal of Asian Education, 1(2), 73-80. https://doi.org/10.46966/ijae.v1i2.36.

Rusydiyah, E. F., Indrawati, D., Jazil, S., Susilawati, \& Gusniwati. (2021). Stem learning environment: Perceptions and implementation skills in prospective science teachers. Jurnal Pendidikan IPA Indonesia, 10(1), 138-148. https://doi.org/10.15294/jpii.v10i1.28303.

Setianingrum, R. S., Syamsuri, S., \& Setiani, Y. (2020). Analyzing Students' Learning Difficulties In Algebra. MaPan : Jurnal Matematika Dan P(1). https://doi.org/10.24252/mapan.2020v8n1a2.

Shofiah, Lukito, \& Siswono. (2018). Pembelajaran Learning Cycle 5E Berbasis Pengajuan Masalah untuk Meningkatkan Hasil Belajar Siswa Kelas X pada Topik Trigonometri. Jurnal Matematika Kreatif, 9(1), 54-62. https://doi.org/10.15294/kreano.v9i1.9856.

Solé-Llussà, Anna, Aguilar, D., \& Ibáñez, M. (2019). Video worked examples to promote elementary students' science process skills: a fruit decomposition inquiry activity. Journal of Biological Education, 1. https://doi.org/10.1080/00219266.2019.1699149.

Sorensen, E. (2013). Implementation and student perceptions of e-assessment in a Chemical Engineering module. European Journal of Engineering Education, 38(2), 172-185. https://doi.org/10.1080/03043797.2012.760533.

Stender, A., Schwichow, M., Zimmerman, C., \& Härtig, H. (2018). Making inquiry-based science learning visible: the influence of CVS and cognitive skills on content knowledge learning in guided inquiry. International Journal of Science https: //doi.org/10.1080/09500693.2018.1504346.

Stover, K., Yearta, L., \& Harris, C. (2016). Experiential Learning for Preservice Teachers: Digital Book Clubs With Third Graders. Journal of Digital Learning in Teacher Education, 32(1), 5-12. https: //doi.org/10.1080/21532974.2015.1055013.

Suarsana, I. M. (2021). Developing Interactive Digital Mathematics Book with Multi Representation Approach for Deaf Students. International Journal of Emerging Technologies in Learning, 16(13). https://doi.org/10.3991/ijet.v16i13.22459.

Suratmi, Laihat, \& Asnimar. (2020). Development of Assessment Instruments Based on Higher Order Thinking Skills (HOTS) for Elementary School Students. Jurnal Pendidikan Sekolah Dasar (JPsd), 6(1), 199-211. https://doi.org/10.30870/jpsd.v6i2.7356.

Vartiainen, J., \& Kumpulainen, K. (2020). Playing with science: manifestation of scientific play in early science inquiry. European Early Childhood Education Research Journal, 28(4). https: //doi.org/10.1080/1350293X.2020.1783924.

Wahyuniar, L. S., \& Widyawati, S. (2017). Proses Berpikir Mahasiswa Dalam Menyelesaikan Soal Kombinatorial Berdasarkan Kecerdasan Logis Matematis. Numerical: Jurnal Matematika Dan Pendidikan Matematika, 1(1). https://doi.org/10.25217/numerical.v1i2.177.

Widodo, P. B. (2006). Reliabilitas Dan Validitas Konstruk Skala Konsep Diri Untuk Mahasiswa Indonesia. Reliabilitas Dan Validitas Konstruk Skala Konsep Diri Untuk Mahasiswa Indonesia, 3(1), 1-9. https://doi.org/10.14710/jpu.3.1.1.

Wulandari, F. A., Mawardi, M., \& Wardani, K. W. (2019). Peningkatan Keterampilan Berpikir Kreatif Siswa Kelas 5 Menggunakan Model Mind Mapping. Jurnal Ilmiah Sekolah Dasar, 3(1). https://doi.org/10.23887/jisd.v3i1.17174. 